\title{
Tingkat Pengetahuan tentang Kesehatan Gigi Berhubungan dengan Perilaku Perawatan Gigi pada Anak Usia 10-12 Tahun.
}

(Level of Knowledge obout Dental Health Related to Dental Care Behavior in Children 10-12 Years Old)

Syaifurrahman Hidayat, Elyk Dwi Mumpuningtias, Putri Sari Andriyani

Program Studi Keperawatan. Fakultas Ilmu Kesehatan. Universitas Wiraraja

\begin{abstract}
Abstrak
Kesehatan gigi dan mulut bertujuan untuk mencegah terjadinya lubang pada gigi sebagai penyebab utama infeksi pada organ lain di rongga mulut. Pengetahuan orang tua merupakan faktor yang menentukan perilaku perawatan gigi dan mulut sejak dini dalam merawat kesehatan gigi dan mulut. Tujuan penelitian untuk mengetahui hubungan antara tingkat pengetahuan tentang kesehatan gigi dengan perilaku perawatan gigi pada anak usia 1012 tahun. Jenis penelitian yang digunakan adalah cross sectional. Variabel bebas adalah pengetahuan tentang perawatan gigi dan variabel terikat adalah perilaku perawatan gigi. Waktu penelitian satu bulan di SD Banasare 1 Kecamatan Rubaru. Populasi dan sampel seluruh siswa kelas IV dan V. Teknik pengambilan sampel menggunakan total populasi. Instrumen penelitian berupa angket dan perilaku perawatan gigi. Analisis data menggunakan Spearman dengan a $(0,05)$. Hasil penelitian menunjukkan bahwa hampir semua pengetahuan kesehatan gigi baik yaitu sebanyak 40 orang (93,0\%). Hampir semua perilaku perawatan gigi baik yaitu sebanyak 40 orang (93,0\%). Hasil analisis data diperoleh $\mathrm{p}$ value $=0,000$ dengan $a=0,005$, maka $\mathrm{p}$ value $(0,000)<\mathrm{a}(0,005)$ maka H0 ditolak yang artinya ada hubungan antara tingkat pengetahuan tentang kesehatan gigi dengan perilaku perawatan gigi pada anak. usia 10-12 tahun di SDN Banasare I, Kecamatan Rubaru. Upaya peningkatan kesehatan gigi dan mulut dapat dilakukan melalui promosi kesehatan di SD Banasare I. Promosi efektif dilakukan dengan cara mencontohkan cara merawat gigi menggunakan alat peraga secara terus menerus setiap bulan sehingga konsistensi perilaku dapat terbentuk dan terjaga.
\end{abstract}

Kata kunci: anak usia 10-12 tahun, perawatan gigi, tingkat pengetahuan

\section{Abstract}

The health of the teeth and mouth aims to prevent the occurrence of holes in the teeth as the main cause of infection in other organs in the oral cavity. Knowledge of parents is a factor that determines oral and dental care behavior early in treating oral and dental health. The purpose of the study was to determine the relationship between the level of knowledge about dental health and dental care behavior in children aged 10-12 years. This type of research was cross sectional. The independent variable was knowledge about dental care and the dependent variable was dental care behavior. One month research time at Banasare 1 Elementary School, Rubaru Subdistrict. Population and sample of all grade $I V$ and $V$ students. The sampling technique used the total population. The research instrument was questionnaire and dental care behavior. Data analysis used Spearman with a (0.05). The results showed that almost all dental health knowledge was good, as many as 40 people (93.0\%). Almost all dental care behaviors were good, as many as 40 people (93.0\%). The results of data analysis obtained $\mathrm{p}$ value $=0,000$ with $a=0.005$, so $\mathrm{p}$ value $(0,000)<\mathrm{a}(0,005)$ then $\mathrm{HO}$ is rejected which means there was a relationship between the level of knowledge about dental health and dental care behavior in children aged 10-12 years in SDN Banasare I, Rubaru District. Efforts to improve dental and oral health can be done through health promotion at Banasare Elementary School I. Effective promotion was done by exemplifying how to treat teeth using props continuously every month so that consistency of behavior can be formed and maintained.

Keywords: children aged 10-12 years, dental care, knowledge

Korespondensi (Correspondence) : Syaifurrahman Hidayat. Program Studi Keperawatan, Fakultas IImu Kesehatan, Universitas Wiraraja. Jl. Raya Sumenep-Pamekasan km 05 Patean, Batuan, Kabupaten Sumenep, Jawa Timur 69451.Email: dayat.fik@wiraraja.ac.id

Gigi dan mulut merupakan bagian anggota tubuh yang penting untuk dijaga kebersihannya. Kesehatan gigi dan mulut adalah hal paling utama untuk mencegah terjadinya lubang pada gigi karena lubang gigi adalah penyebab utama terjadinya infeksi pada organ lain dalam rongga mulut.

Kesehatan gigi dan mulut berpengaruh terhadap kesehatan tubuh kita. Oleh karena itu kondisi sakit pada gigi dapat menganggu individu dalam mengkonsumsi makanan, sehingga akan mengakibatkan gangguam dalam memenuhi asupan sutrisi tubuh dan akan mengakibatkan tubuh lemah dalam beraktivitas. ${ }^{2}$ Kesehatan gigi dan mulut bagian utama yang perlu dijada dan dipertahankan kesehatnnya. Berdasarkan data WHO dalam
The World Oral Health Report maslah kesehatan gigi dan mulut mencapai $90 \%$ masyarakat Indonesia masih banyak yang mengalami masalah pada kesehatan gigi dan mulut. Dari berbagai macam kasus yang menyerang masyarakat Indonesia mayoritas adalah karies gigi.

Anak usia 10-12 tahun belum mengerti dalam perawatan kebersihan gigi dan mulut, sebabnya dalam melakukan gosok gigi masih belum benar, waktu menggosok gigi dan cara penggunaan pasta gigi. ${ }^{3}$ Cara menggosok gigi yang benar dilakukan setelah makan di pagi hari dan malam hari sebelum tidur serta dengan menggosok seluruh permukaan luar dan dalam gigi sehingga tidak berakibat pada kerusakan gigi. ${ }^{4}$ Anak yang tinggal di 
pedesaan dengan usia 4-5 tahun mengalami 95,9\% karies gigi. Survei Kesehatah Rumahangga (SKRT) tahun 2012 menyebutkan kenaikan masalah gigi gengan karies pada anak diatas umur 10 tahun mencapai 55\% serta mengalami peningkatan seiring dengan bertambahnya umur sebesar 65\%. Namun, belum mencapai target 2014 sebesar $95 \%$. Kegemaran anak usia 2-5 tahun mempunyai kebiasaan mengkonsumsi makanan yang mengandung karsinogen sehingga akan sering melekat dalam celahcelah permukaan giginya, dan orang tua mayoritas sudah kurang memperdulikan kebiasaannya menyikat gigi, utamanya malam menjelang tidur. Jika seorang anak sudah tidak dibiasakan menyikat gigi, maka kebiasaan tersebut akan berpotensi menimbulkan karies gigi pada anak. Salah satu faktor-faktor yang bisa mencegah karies pada gigi anak memberikan pengetahuan kepada orang tua dalam menjaga kesehatan gigi dan mulut.

Cara merawat gigi dan mulut yang dilakukan dengan baik dimulai dari usia dini maka akan menjadikan dasar terciptanya perilaku yang positif pada anak dalam merawat kesehatan gigi dan mulutnya. Pengetahuan tersebut dapat diperoleh dengan terencana yaitu melalui proses pendidikan maupun secara alami. Pengetahuan orang tua yang minim terhadap kesehatan gigi dan mulut adalah salah satu faktor penyebab dari perilaku yang kurang baik pada kesehatan gigi dan mulut pada anak. Dari hasil pancaindra yang dimiliki manusia melalui pendengaran, pengetahuan dan penglihatan dapat menjadi faktor seseorang berperilaku dalam keseharianya.

Semakin tinggi anak mengetahui cara pemeriksaan gigi maka akan semakit bik pula kesehatan pada gigi dan mulut. Dalam penelitian ini penelititertarik untuk melakukan penelitian tentang tingkat pengetahuan tentang kesehatan gigi berhubungan dengan perilaku perawatan gigi pada anak usia 10-12 tahun

\section{METODE PENELITIAN}

Penelitian ini dilaksanakan pada bulan Mei 2019 dengan desain observasional menggunakan desain Cross Sectional dengan melakukan penelitian pada waktu yang sama mengambil informasi pada variable bebas dan variable terikat dan dinilai secara simultasi pada saat penelitian berlangsung. 5 Sampel pada penelitian ini adalah sebagian dari anak usia sekolah kelas IV dan V sebanyak 43 siswa dengan teknik total sampling. dengan perilaku perawatan gigi pada anak usia 10-12 tahun di SDN bana sare I Kecamatan Rubaru.

Pengumpulan data dilakukan dengan wawancara dipandu menggunakan pengisian kuesioner. Analisa data pada penelitian ini menggunakan uji Spearman Rank untuk menegetahui hubungan tingkat pengetahuan tentang kesehatan gigi.

\section{HASIL PENELITIAN}

Tabel 1. Jenis Kelamin Responden

\begin{tabular}{|c|c|c|}
\hline Jenis Kelamin & $\mathbf{N}$ & $\%$ \\
\hline Laki-laki & 20 & 46,51 \\
\hline Perempuan & 23 & 53,49 \\
\hline Total & 43 & 100 \\
\hline
\end{tabular}

Tabel 2. Umur responden

\begin{tabular}{|c|c|c|}
\hline Umur & $\mathbf{N}$ & $\%$ \\
\hline 10 Tahun & 9 & 20,93 \\
\hline 11 Tahun & 11 & 25,58 \\
\hline 12 Tahun & 23 & 53,49 \\
\hline Total & 43 & 100 \\
\hline
\end{tabular}

Tabel 3. Tingkat Pengetahuan tentang Kesehatan Gigi

\begin{tabular}{|c|c|c|}
\hline Tingkat Pengetahuan & $\mathbf{N}$ & $\%$ \\
\hline Kurang & 1 & 2,3 \\
\hline Cukup & 2 & 4,7 \\
\hline Baik & 40 & 93 \\
\hline Total & 43 & 100 \\
\hline
\end{tabular}

Tabel 4. Perilaku Perawatan Gigi pada Anak Usia 10-12 Tahun

\begin{tabular}{lcc}
\hline Perilaku Perawatan Gigi & N & $\%$ \\
\hline Kurang & 1 & 2,3 \\
Cukup & 2 & 4,7 \\
Baik & 40 & 93 \\
\hline Notal & 43 & 100 \\
\hline jumlah responden; \%, persentase &
\end{tabular}

Tabel 1, 2, dan 3 menggambarkan tentang demografi responden yang meliputi distribusi jenis kelamin, umur dan tingkat pengetahuan. Tabel 1 menunjukkan sebagian besar responden berjenis kelamin perempua yaitu sebanyak 23 orang $(53,49 \%)$. Tabel 2 menunjukkan sebagian besar responden berumur 12 Tahun yaitu sebanyak 23 orang (53,49\%). Tabel 3 menunjukkan bahwa sebagain besar responden memilki tingkat pengetahuan pada kategori baik sebanyak 40 responden (93\%).

Tabel 4 menunjukkan pembagian responden berdasarkan perilaku cara merawat ggi. Sebagian besar responden memilki Perilaku Perawatan Gigi pada Anak Usia 10-12 Tahun pada kategori baik sebanyak 40 responden (93\%).

Tabel 5. Hubungan Tingkat Pengetahuan tentang Kesehatan Gigi dengan Perilaku Perawatan Gigi

\begin{tabular}{ccccccccc}
\hline $\begin{array}{c}\text { Pengetahuan } \\
\text { Kesehatan } \\
\text { Gigi }\end{array}$ & \multicolumn{6}{c}{ Perilaku Perawatan Gigi } \\
\cline { 2 - 10 } & Kurang & \multicolumn{1}{c}{ Cukup } & \multicolumn{3}{c}{ Baik } & \multicolumn{2}{c}{ Total } \\
\cline { 2 - 9 } & $\mathbf{f}$ & $\mathbf{f}$ & $\mathbf{6}$ & $\mathbf{F}$ & $\mathbf{\%}$ & $\mathbf{F}$ & $\mathbf{\%}$ \\
\hline Kurang & 1 & 100 & 0 & 0 & 0 & 0 & 1 & 100 \\
Cukup & 0 & 0 & 2 & 100 & 0 & 0 & 2 & 100 \\
Baik & 0 & 0 & 0 & 0 & 40 & 100 & 40 & 100 \\
\hline Total & $\mathbf{1}$ & $\mathbf{2 , 3}$ & $\mathbf{2}$ & $\mathbf{4 , 7}$ & $\mathbf{4 0}$ & $\mathbf{9 3}$ & $\mathbf{4 3}$ & $\mathbf{1 0 0}$ \\
\hline
\end{tabular}

$\mathrm{N}$, jumlah responden; \%, persentase 
Tabel 5 menunjukkan bahwa responden dengan pengetahuan kesehatan gigi kurang seluruhnya memiliki perilaku perawatan gigi kurang 1 (100,0\%). Responden dengan pengetahuan kesehatan gigi cukup seluruhnya memiliki perilaku perawatan gigi cukup 2 $(100,0 \%)$. Responden dengan pengetahuan kesehatan gigi baik seluruhnya memiliki perilaku perawatan gigi baik 40 (100,0\%).

\section{PEMBAHASAN}

Hasil analisa data menggunakan uji Spearman Rho diperoleh $p$ value $=0,000$ dengan nilai $=0,05$, jadi $\mathrm{p}(0,000)<(0,05)$ maka HO ditolak yang bermakna ada hubungan tingkat pengetahuan tentang kesehatan gigi dengan perilaku perawatan gigi pada anak usia 10-12 tahun di SDN Banasare I Kecamatan Rubaru.

Hasil penelitian Yusmanijar \& Mulyanah A (2019) membuktikan bahwa terdapat hubungan antara tingkat pengetahuan tentang kesehatan gigi dan mulut dengan perilaku perawatan gigi dan mulut pada anak usia sekolah 7-9 dimana penelitian ini mendukung secara ilmiah bahwa semakin tinggi tingkat pengetahuan sesoorang maka akan semakin baik pula perilaku seseorang dalam menjaga kesehatan. 6

Menurut Notoatmodjo,

(2010)

menyatakan bahwa behaviorcauses dan non behaviour causes dapat mempengaruhi individu, Selanjutnya perilaku seseorang dapat terbentuk oleh faktor predisposisi yang mencakup nurna, nilai-nilai, pengamalan dan pengetahuan seseorang. ${ }^{7}$ Sehingga terori tersebut mendukung bahwa terjadinya perubahan peningkatan perilaku kesehatan yang disebabkan oleh pengetatuan yang baik pada individu.

Tingkat pendidikan dapat mempengaruhi kognitif individu dalam tentang pengetahuan. Anak usia 10-12 Tahun yang sudah mulai mengikuti pendidikan dibangku sekolah dapat meningkatkan pengetahuannya dimana ilmu tentang pendidikan kesehatan dapat diterima baik secara formal maupun informal, sehingga dengan pendidikan yang semakin tinggi seorang anak akan selalu mencari ilmu bisa dari guru di sekolah atau melalui kedua orang tuanya. Sementara itu, dalam penelitian ini akan mempengaruhi perilaku perawatan gigi sehingga kesehatan gigi pada anak meningkat.

Dengan memberikan informasi-informasi tentang perawatan gigi pada anak akan meningkatkan pengetahuan anak dalam memelihara kebersihan dan kesehatan gigi, Pengetahuan akan menghasilkan sebuah kesadaran pada individu, yang pada akhirnya akan mengubah perilaku sesuai dengan informasi atau ilmu yang dimilikinya. Perubahan perilaku pada individu tidak dapat dilakukan dalam waktu yang singkat, dikarenakan perubahan yang diharapkan dapat berubah secara siknifikan dengan didasari oleh kesadaran pada individu sehingga akan terjadi terus menerus. ${ }^{7}$

Perilaku Kesehatan merurut Pender merupakan teori nilai harapan meyakini bahwa perilaku tertentu dimunculkan untuk mendapatkan hasil tertentu, hasil inilah yang akan menjadi nilai personal yang positif. Sementara teori kognitif sosial berfokus pada konsep kemampuan diri, yaitu penilaian individu terhadap kemampuan diri untuk berperilaku tertentu, sehingga perilaku Perawatan Gigi pada Anak Usia 10-12 Tahun merupakan bagian dari hasil tindakan dalam menjaga kesehatan. ${ }^{8}$

Pemberian pendidikan kesehatan mampu meningkatkan komitmen seseorang untuk melakukan perilaku kesehatan. Komitmen orang tua dalam mendidika anak dalam melakukan perawatan kesehatan gigi merupakan pola untuk meningkatkan kesehatan setelah mendapatkan pendidikan kesehatan tentang kesehatan gigi.?

Berdasarkan hasil penelitian dapat disimpulkan tingkat pengetahuan tentang kesehatan gigi dan perilaku perawatan gigi pada anak usia 10-12 tahun bahwa sebagian besar kategori baik sebanyak 40 responden 193 $\%)$ dan ada hubungan yang bermakna antara tingkat pengetahuan tentang kesehatan gigi dengan perilaku perawatan gigi pada anak usia 10-12 tahun di SDN Banasare I Kecamatan Rubaru.

\section{DAFTAR PUSTAKA}

1. Erwana AF. Seputar Kesehatan Gigi dan Mulut.Yogyakarta: Rapha Publishing. 2013

2. Mumpuni Yekti\& Pratiwi Erlita. 45 Masalah \& Solusi Penyakit Gigi \& Mulut. Yogyakarta: Rapha Publishing. 2013

3. Andini A dan Tjahyadi. Gigi Sehat Ibadah Dasyat. Yogjakarta: Pro-U Media. 2011

4. Hidayat R dan Tandiari A. Kesehatan Gigi dan Mulut - Apa yang Sebaiknya Anda Tahu?.Yogyakarta: Cv Ando Offiset. 2016

5. Nursalam. Metodologi Penelitian IImu Keperawatan: Pendekatan Praktis Edisi 4_ Jakarta: Salemba Medika. 2016

6. Yusmanijar dan Mulyanah. Hubungan Tingkat Pengetahuan tentang Kesehatan Gigi dan Mulut dengan Perilaku Perawatan Gigi dan Mulut pada Anak Usia Sekolah 7-9 Tahun di SD Islam Al Amal Jati Cempaka. Jurnal Afiat: Kesehatan dan Anak. 2019; 5(1).

7. Notoatmodjo S. Metodologi Penelitian Kesehatan. Jakarta: Rineka Cipta. 2010.

8. Alligood MR \& Tomey AM. Nursing Theorist and Their Work (7th ed). Mosby Elsevier. 2010. 
9. Goodarzi-Khoigani M., Baghiani Moghadam M., Nadjarzadeh A., Mardanian F., Fallahzadeh H., \& Mazloomy-Mahmoodabad S. Impact of nutrition education in improving dietary pattern during pregnancy based on pender's health promotion model: A randomized clinical trial. Iranian Journal of Nursing and Midwifery Research, 2018; 23(1): 18. 